\title{
Detection and Separation of Inorganic Cations in Natural, Potable, and Wastewater Samples Using Capillary Zone Electrophoresis with Indirect UV Detection
}

\author{
Lara Varden, Fadi Bou-Abdallah* \\ Department of Chemistry, State University of New York (SUNY) at Potsdam, Potsdam, NY, USA \\ Email: *bouabdf@potsdam.edu
}

How to cite this paper: Varden, L. and Bou-Abdallah, F. (2017) Detection and Separation of Inorganic Cations in Natural, Potable, and Wastewater Samples Using Capillary Zone Electrophoresis with Indirect UV Detection. American Journal of Analytical Chemistry, 8, 81-94.

http://dx.doi.org/10.4236/ajac.2017.81007

Received: December 11, 2016

Accepted: January 13, 2017

Published: January 16, 2017

Copyright $\odot 2017$ by authors and Scientific Research Publishing Inc. This work is licensed under the Creative Commons Attribution International License (CC BY 4.0).

http://creativecommons.org/licenses/by/4.0/

\begin{abstract}
Capillary zone electrophoresis (CZE) is a sensitive and rapid technique for determining traces of inorganic cations in water samples. CZE with indirect UV-diode array detection (CZE-DAD) was utilized to identify several inorganic cations in natural, potable, and wastewater samples. A pH 4.35 background electrolyte system was employed and consisted of $15 \mathrm{mM}$ imidazole, 8 $\mathrm{mM}$ malonic acid, $2 \mathrm{mM} 18$-crown- 6 ether as complexing agents, $10 \% \mathrm{v} / \mathrm{v}$ methanol as an organic modifier with indirect absorbance reference at 214 $\mathrm{nm}$. The CZE method involved electromigration injection at $5 \mathrm{kV}$ for $5 \mathrm{~s}$, a separation voltage of $20 \mathrm{kV}$ at $25^{\circ} \mathrm{C}$, and a detection wavelength of $280 \mathrm{~nm}$. Six main cations (ammonium $\mathrm{NH}_{4}^{+}$, potassium $\mathrm{K}^{+}$, calcium $\mathrm{Ca}^{2+}$, sodium $\mathrm{Na}^{+}$, magnesium $\mathrm{Mg}^{2+}$, and lead $\mathrm{Pb}^{2+}$ ) were tested, and all but lead, were detected in the water samples at concentrations between 0.03 and $755 \mathrm{ppm}$ with a detection limit ranging between 0.023 and $0.084 \mathrm{ppm}$. The successful evaluation of the proposed methodology allowed us to reliably detect and separate six metal ions in different water samples without any pretreatment. All water samples were collected from Northern New York towns and the Raquette River water system, the third longest river in New York State and the largest watershed of the central and western Adirondacks.
\end{abstract}

\section{Keywords}

Capillary Zone Electrophoresis, Indirect UV Detection, Inorganic Cations, Northern New York Raquette River, Adirondack Watershed

\section{Introduction}

In 1937, Tiselius introduced electrophoresis as a separation technique for which 
he received a Nobel Prize [1]. In 1981, Jorgenson and Lukas modernized the technique by utilizing fused silica capillaries while also clarifying the theory of the relationship between separation quality and operational parameters. They demonstrated capillary electrophoresis (CE) separation as an analytical technique based on the differences in solute velocity in an electric field [2]. Since its inception, CE has become a well-established analytical technique used in laboratories worldwide. Compared to other separation techniques, the CE offers short analysis times, highly efficient separation, and minimal consumption of solvents, reagents and samples. CE has shown to be quite successful and efficient in the analysis of small molecules and has even produced higher separation efficiency compared to HPLC (High Performance Liquid Chromatography) [3], ASS (atomic absorption spectrometry, IC (ion chromatography), and ICP-MS (inductively coupled plasma with mass spectrometry) [4] in testing of water samples while consuming lower sample volumes [5]. In capillary zone electrophoresis (CZE), one of many electrophoretic techniques of CE, the molecules are separated based on their size to charge ratio and there exist numerous examples in the literature [6]-[12]. When implementing commercial CE instruments for the separation and analysis of non-absorbing ions, indirect-UV methods are most advantageous. Notwithstanding that the indirect technique is not as sensitive as the direct technique, the separation medium must provide quality resolution of the ion zones, precise sample zones, and a running buffer with high direct-UV absorbance in order to detect low ions concentration in actual samples [13].

Nine essential inorganic ions $\left(\mathrm{Na}^{+}, \mathrm{K}^{+}, \mathrm{Ca}^{2+}, \mathrm{Mg}^{2+}, \mathrm{H}^{+}, \mathrm{Cl}^{-}, \mathrm{HCO}_{3}^{-}, \mathrm{PO}_{4}^{3-}\right.$, and $\mathrm{OH}^{-}$) are naturally present in water with a significant role in supporting and maintaining health and life [14]. Unfortunately, over the last few decades, water supplies used for drinking, washing, agriculture, fishing and even recreation have become more and more contaminated on a global scale. The quality of water is regulated in the United States via the Clean Water Act (CWA) of 1972 [15], which primarily governs water pollution of surface waters, and the Safe Drinking Water Act (SDWA) of 1974 that deals mainly with sources of drinking water and groundwater contamination. These water Acts are instituted federally by the United States Environmental Protection Agency (US EPA). The SDWA only regulates 91 contaminants, yet the United States uses in excess of 80,000 chemicals, according to US EPA estimates. The New York State Department of Environmental Conservation (NYSDEC) water quality standards program is a state program with federal oversight by the US EPA, which pre-exists the federal Clean Water Act and protects surface waters as well as groundwaters. Table 1 shows a list of cations of interest to this study listing US EPA's and NYSDEC's [16] regulation standards, source or cause, and health significance.

In this study, the main objective was to test and optimize CE methods to detect and quantify certain cations present in natural water, drinking water, and wastewater samples from the Raquette River water system and other local communities. Water samples were obtained at numerous sites in the Northern New York area, primarily of the Raquette River water system, which is the third longest 
Table 1. Water-quality criteria for several cations tested in this study. All regulated standards are from US Environmental Protection Agency, US EPA [15], and New York State Department of Environmental Conservation, NYSDEC [16].

\begin{tabular}{|c|c|c|c|}
\hline Constituent & Standard & Source or Cause & Significance \\
\hline $\begin{array}{l}\text { Ammonium/Ammonia } \\
\left(\mathrm{NH}_{3}+\mathrm{NH}_{4}^{+} \text {as } \mathrm{N}\right)\end{array}$ & $2 \mathrm{mg} / \mathrm{L}^{\star *}$ & $\begin{array}{l}\text { Decomposition of animal and plant proteins, } \\
\text { agricultural, urban runoff, and effluent from } \\
\text { wastewater treatment plants or industrial } \\
\text { contamination. }\end{array}$ & $\begin{array}{l}\text { Can cause unwanted algal blooms. Can indicate } \\
\text { sewage pollution and consequent possible presence } \\
\text { of pathogenic microorganisms. }\end{array}$ \\
\hline Calcium $\left(\mathrm{Ca}^{2+}\right)$ & --- & $\begin{array}{l}\text { Occurs in rocks, bones, shells, etc. } \\
\text { Very abundant. }\end{array}$ & $\begin{array}{l}\text { Causes water hardness. Essential for normal } \\
\text { growth and health ( } 1-2 \mathrm{~g} \text { daily requirement). }\end{array}$ \\
\hline Lead $\left(\mathrm{Pb}^{2+}\right)$ & $\begin{array}{l}\mathrm{MCL} \\
15 \mu \mathrm{g} / \mathrm{L}^{*} \\
50 \mu \mathrm{g} / \mathrm{L}^{* *}\end{array}$ & $\begin{array}{l}\text { Leaching from ores and erosion of natural } \\
\text { deposits; effluent discharges; corrosion of } \\
\text { household plumbing systems. }\end{array}$ & $\begin{array}{l}\text { A cumulative poison particularly in infants and } \\
\text { children; Delays physical and mental development; } \\
\text { May cause kidney problems and high blood } \\
\text { pressure in adults. }\end{array}$ \\
\hline Magnesium $\left(\mathrm{Mg}^{2+}\right)$ & $35 \mathrm{mg} / \mathrm{L}^{* *}$ & $\begin{array}{l}\text { Major constituent of geological } \\
\text { formations. }\end{array}$ & $\begin{array}{l}\text { A major dietary requirement for humans } \\
(0.3-0.5 \mathrm{~g} / \text { day }) \text { and the second major } \\
\text { constituent of water hardness. }\end{array}$ \\
\hline Potassium $\left(\mathrm{K}^{+}\right)$ & --- & Geological formations. & No health concerns except at gross levels. \\
\hline Sodium $\left(\mathrm{Na}^{+}\right)$ & $20 \mathrm{mg} / \mathrm{L}^{* *}$ & Abundant constituent of rocks and soils. & $\begin{array}{l}\text { Essential dietary requirement ( } 5 \mathrm{~g} \text { or more). } \\
\text { Causes hypertension if in excess. }\end{array}$ \\
\hline
\end{tabular}

MCL, Maximum Contaminant Level (highest level of a contaminant that is allowed in drinking water); ---, no limit established; ${ }^{*}$ US EPA standard; ${ }^{* *}$ NYSDEC standard.

river in New York State and the largest watershed of the central and western Adirondacks. The river system begins at Blue Mountain Lake, flows south to Raquette Lake, turns northeast to Long Lake, heads north to Tupper Lake through the Adirondack Park, continuing north where it finally empties into the St. Lawrence River, northeast of Massena and bordering Canada. The Raquette River is one of the most popular, recreationally traveled and fished rivers of the Adirondack Park. Historically, every community along the River drew their drinking water from this river system; but due to changes in water quality of this watershed, only a handful of communities still draw their drinking water out of this source. The rest have been forced by the New York State Department of Health (NYSDOH) regulations on water quality to obtain their drinking water from deep-water wells. The village of Potsdam in Upstate New York resides on the banks of the Raquette River and is the largest user of drinking water drawn off the River in addition to two local universities, State University of New York at Potsdam and Clarkson University.

\section{Materials and Methods}

\subsection{Chemicals}

Lead chloride and glacial acetic acid were purchased from Fisher Scientific (Fairlawn, NJ, USA), imidazole and malonic acid were obtained from Aldrich (Milwaukee, WI, USA), 18-crown-6 ether was acquired from Sigma-Aldrich (St. Louis, MO, USA), and methanol was attained from Pharmco-Aaper (Brookfield, CT, USA). All reagents were of analytical grade. Ultra pure CE water obtained from Agilent Technologies (Santa Clara, CA, USA). 


\subsection{Standards and BGE}

Agilent's Cation Test Mixture stock (100 ppm each of ammonium, potassium, calcium, sodium, magnesium) was diluted to $25 \mathrm{ppm}$ with DI water and 250 ppm lead from 1000 ppm stock of lead (chloride salt) dissolved in DI water obtained from EMD Millipore Elix10 Water Purification System (Darmstadt, Germany). The standard mixture was filtered using a $0.22 \mu \mathrm{m}$ PES syringe filter (Argos Technologies, Elgin, IL, USA). The running buffer or BGE (background electrolyte) consisted of $15 \mathrm{mM}$ imidazole, $8 \mathrm{mM}$ malonic acid, $2 \mathrm{mM}$ 18-crown-6 ether, $10 \% \mathrm{v} / \mathrm{v} \mathrm{MeOH}$ with $\mathrm{pH}$ adjusted to 4.35 using $50 \% \mathrm{v} / \mathrm{v}$ acetic acid. All chemicals were dissolved in DI water. Buffer was filtered using $0.22 \mu \mathrm{m}$ PES membrane syringe filter and degassed for $10 \mathrm{~min}$ using TA Instruments degassing station (New Castle, DE, USA) in $2 \mathrm{~mL}$ glass CE vials (Agilent Technologies) prior to runs.

\subsection{Instrumentation}

The capillary electrophoresis system employed in this study is the Agilent G7100 with a UV-DAD (diode array detector) interfaced with ChemStation software for data acquisition (Agilent Technologies, Santa Clara, CA, USA). The separation capillary used was a standard bare fused silica by Agilent Technologies measuring $64.5 \mathrm{~cm}$ total length, $56 \mathrm{~cm}$ effective length, and an internal diameter (i.d.) of $75 \mu \mathrm{m}$.

\subsection{Procedures}

Prior to first use and daily conditioning of capillary included flushing with $0.1 \mathrm{M}$ $\mathrm{NaOH}$ for $10 \mathrm{~min}$, ultra-pure water for $10 \mathrm{~min}$, and running buffer/BGE for 15 min. The capillary was conditioned between runs with 5 min of BGE. Conditioning of the capillary at the end of the day included 15 min ultra-pure water flush and $3 \mathrm{~min}$ air flush. The separation was completed with a voltage at $20 \mathrm{kV}$ (positive polarity) and the capillary cassette was kept at $25^{\circ} \mathrm{C}$ for all experiments. Sample injection was performed under electromigration injection at $5 \mathrm{kV}$ for $5 \mathrm{~s}$. Detection was at UV signal of $280 \mathrm{~nm}(20 \mathrm{~nm}$ bandwidth) with an indirect reference signal of $214 \mathrm{~nm}$ (10 $\mathrm{nm}$ bandwidth), and a runtime of $12 \mathrm{~min}$. Each sample was run at least three times to ensure reproducibility and the results in Table 2 are average values from multiple experiments with less than $5 \%$ uncertainty.

\subsection{Samples}

All water samples (natural river waters, potable tap and well waters, and wastewaters, pre- and post-treatment) were collected in BPA-free plastic gallon water containers and filtered through a $0.22 \mu \mathrm{m}$ PES syringe filter by Agros. No further manipulation of water samples (i.e. dilution, concentration, $\mathrm{pH}$ adjustment, complexation, etc.) was performed so as to mimic natural water conditions during testing. Water samples were obtained from water sources feeding areas of interest, mainly Raquette River system from Tupper Lake (TL), NY, to Potsdam, 
Table 2. Concentration of inorganic cations ( $\mathrm{ppm}$ ) detected in water samples tested in this study. Each sample was run at least three times to ensure reproducibility and the results below are average values from multiple experiments with less than $5 \%$ uncertainty. The high ppm values of some of the cations were estimated by extrapolation using the calibration curves of Figure 4.

\begin{tabular}{|c|c|c|c|c|c|c|c|}
\hline \multirow{2}{*}{ Site } & \multirow{2}{*}{ Sample location } & \multicolumn{5}{|c|}{ Concentration levels (ppm) } & \multirow[b]{2}{*}{$\mathrm{Pb}^{2+}$} \\
\hline & & $\mathrm{NH}_{4}^{+}$ & $\mathrm{K}^{+}$ & $\mathrm{Ca}^{2+}$ & $\mathrm{Na}^{+}$ & $\mathrm{Mg}^{2+}$ & \\
\hline $\mathrm{R} 1$ & $\begin{array}{l}\text { Raquette River, upriver from } \\
\text { Tupper Lake, at the Crusher }\end{array}$ & $<0.05$ & $<0.03$ & 47 & 85 & 0.79 & --- \\
\hline $\mathrm{R} 2$ & Pre-WWT in Tupper Lake & 11 & 0.7 & 254 & 2.5 & 0.25 & --- \\
\hline R3 & Post-WWT in Tupper Lake & --- & 0.62 & 364 & 47 & 0.52 & --- \\
\hline $\mathrm{R} 4$ & Carry Falls Reservoir & $<0.05$ & $<0.03$ & 52 & 80 & 0.85 & --- \\
\hline R5 & South Colton Reservoir & $<0.05$ & $<0.03$ & 144 & 122 & 0.97 & --- \\
\hline R6 & Pre-WWT in Potsdam & --- & 0.034 & 301 & 112 & 1.5 & --- \\
\hline R7 & Post-WWT in Potsdam & --- & $<0.03$ & 357 & 154 & 1.8 & --- \\
\hline $\mathrm{T} 1$ & Tap water, village of Tupper Lake & $<0.05$ & $<0.03$ & 50 & 63 & 0.21 & --- \\
\hline $\mathrm{T} 2$ & $\begin{array}{l}\text { Tap water, Mt. Morris area } \\
\text { in Tupper Lake }\end{array}$ & 0.054 & $<0.03$ & 73 & 19 & 0.51 & --- \\
\hline $\mathrm{T} 3$ & Tap water, SUNY Potsdam & $<0.05$ & --- & 186 & 19 & 0.74 & --- \\
\hline $\mathrm{T} 4$ & Tap water, SLU in Canton & --- & --- & 0.83 & 282 & 29 & --- \\
\hline T5 & Tap water, village of Canton & --- & $<0.03$ & 3.6 & 260 & 88 & --- \\
\hline W1 & Well water, Town of Potsdam & --- & --- & 755 & $<0.5$ & --- & --- \\
\hline W2 & Well water, Town of Canton & --- & --- & 353 & 281 & 3.1 & --- \\
\hline W3 & Well water, Winthrop & --- & --- & 1.8 & 315 & 221 & --- \\
\hline
\end{tabular}

NY, as well as pre- and post-wastewater treatment (WWT) from the two villages. Tap and well waters from other local areas including Canton and Winthrop, NY, were also tested. Figure 1 depicts Northern New York map of sample site locations.

\section{Results and Discussion}

\subsection{Comparison and Optimization of the CE Method}

Figure 2 displays the electropherograms of standard cation mixtures being separated using varying methods, BGE, and capillaries. The standard cation mixtures represented by electropherograms (a), (b) and (d) of Figure 2 incorporated 5 cations of $100 \mathrm{ppm}$ each (ammonium, potassium, calcium, sodium and magnesium). The cation standard mixture used in the method illustrated by electropherogram Figure 2(c) included 13 cations $\left(\mathrm{K}^{+}, \mathrm{Ca}^{2+}, \mathrm{Na}^{+}, \mathrm{Cu}^{2+}, \mathrm{Pb}^{2+}, \mathrm{Ba}^{2+}\right.$, $\mathrm{Mg}^{2+}, \mathrm{Fe}^{2+}, \mathrm{Zn}^{2+}, \mathrm{Cr}^{3+}, \mathrm{Cd}^{2+}, \mathrm{Li}^{+}$, and $\mathrm{Al}^{3+}$ ) of $3 \mathrm{ppm}$ each with only 9 signals showing up. Six of these cations were unsuccessfully separated. Cations $\mathrm{Na}^{+}$, $\mathrm{Cu}^{2+}, \mathrm{Pb}^{2+}$ and $\mathrm{Ba}^{2+}$ elute at the same time with sodium most likely masking the other three ions. Cations $\mathrm{Li}^{+}$and $\mathrm{Al}^{3+}$ also elute at the same time. 




Figure 1. Left map: Map of New York State and surrounding states in the US, southeastern Canada with shadow/grey box representing the collection site area. Right map: Sample site map of Raquette River water system sites, including pre- and post-treated waste water from Tupper Lake and Potsdam, (R), tap water sites (T), and well water sites (W) in northern New York State, USA. The left image is credited to Jackaranga and Daniel Case under the license "Creative Commons CC BY-SA 4.0".

https://commons.wikimedia.org/wiki/File:Adirondack Park map with Blue Line.svg The right image is credited to Peter Fitzgerald, Jackaranga, Algorerhythms, and Daniel Case under the license "Creative Commons CC BY-SA 4.0”. https://commons.wikimedia.org/wiki/File:Adirondacks regions map.svg

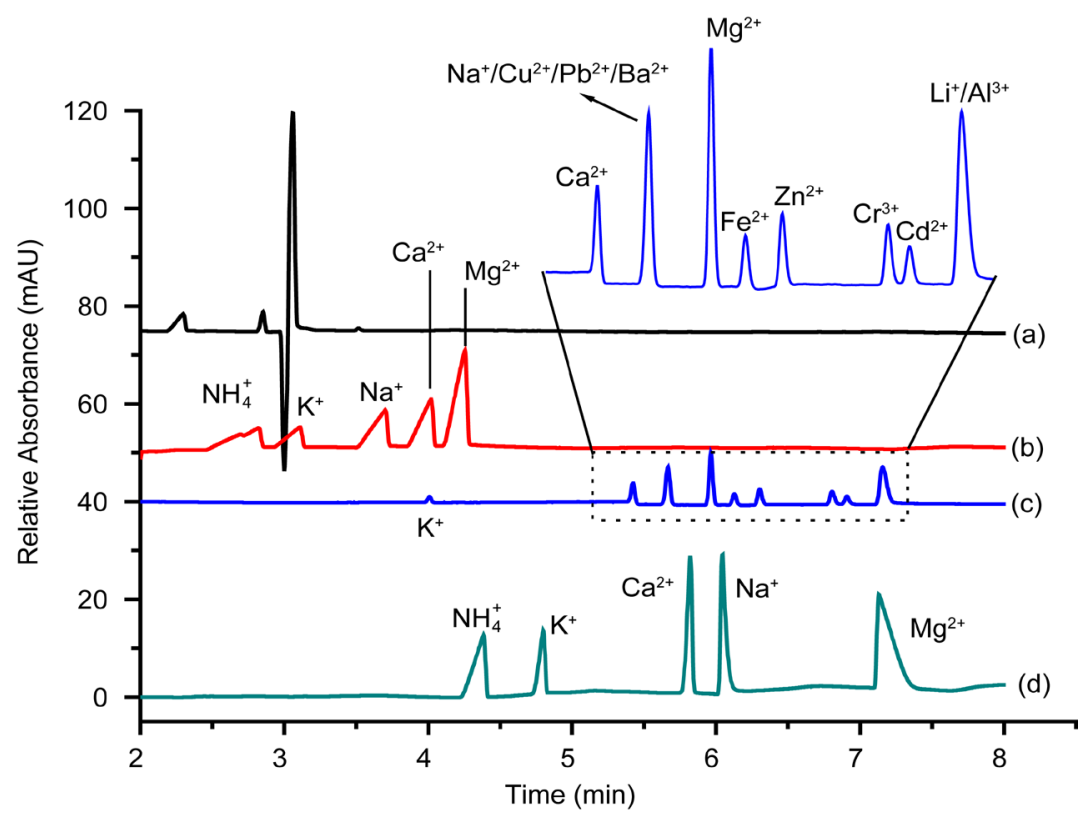

Figure 2. Comparison of electropherograms showing separations of standard cation mixtures using different methods and/or BGEs. The standard cation mixtures were prepared at a concentration of $100 \mathrm{ppm}$ for each cation (ammonium, potassium, calcium, sodium and magnesium). (a) BGE: $5 \mathrm{mM}$ imidazole, $\mathrm{pH}$ 5.1; Separation conditions: $30 \mathrm{kV}, 25^{\circ} \mathrm{C}$, hydrodynamic injection of 35 mbar for $5 \mathrm{~s}$, indirect UV detection at $215 \mathrm{~nm}$; Capillary: bare fused silica, $50 \mu \mathrm{m}$ i.d., $56 \mathrm{~cm}$ length. (b) BGE: Agilent Cation Kit proprietary electrolytes; Separation conditions were the same as in (a); Capillary: extended light path (bubble factor 3, optical path of $150 \mu \mathrm{m}$ ) bare fused silica, 50 $\mu \mathrm{m}$ i.d., $56 \mathrm{~cm}$ length. (c) BGE: $15 \mathrm{mM}$ Imidazole, pH 3.7 (using $17 \mathrm{M}$ glacial acetic acid); Separation conditions: 20 $\mathrm{kV}, 25^{\circ} \mathrm{C}$, hydrodynamic injection of $35 \mathrm{mbar}$ for $5 \mathrm{~s}$, indirect UV detection at $214 \mathrm{~nm}$; Capillary: same as in (b); (d) BGE: $15 \mathrm{mM}$ Imidazole, $8 \mathrm{mM}$ malonic acid, $2 \mathrm{mM} 18$ crown-6, and 10\% v/v methanol, pH 4.35 (using 50\% v/v acetic acid); Separation conditions: $20 \mathrm{kV}, 25^{\circ} \mathrm{C}$, electromigration injection at $5 \mathrm{kV}$ for $5 \mathrm{~s}$, indirect $\mathrm{UV}$ detection at $214 \mathrm{~nm}$; Capillary: bare fused-silica, $75 \mu \mathrm{m}$ i.d., $56 \mathrm{~cm}$ length. 
Sensitivity and selectivity are affected by the background electrolyte (BGE) composition as well as concentration [12]. Separation efficiency is proportional to the concentration of the running buffer [17]. Therefore, the higher the BGE concentration the better the separation efficiency, although too high of BGE concentration could cause large joule heat in the capillary during the run [12]. The running buffer contained imidazole, which acts as background absorption for indirect UV detection. With migration velocities of cations being relatively close together, it can be hard to separate them directly by CE; thus, a weak complexing agent can be used to improve separation efficiency. Since heavy metal ions tend to precipitate out of solution in basic environments, a more acidic solution is preferable for the separation of metal cations.

The results presented in Figure 2 are those of several cation mixtures using different methods and/or BGEs. The detailed experimental conditions for each method are indicated in the figure caption. The electropherogram of Figure 2(a) did not provide decent detection, separation, or selectivity of the cations which may be due to a number of factors including a low running buffer concentration, the absence of a complexing agent, and a high $\mathrm{pH}$. The separation of the cations as observed in Figure 2(b) electropherogram was decent, but the peaks were broad and non-symmetrical. The electropherogram shown in Figure 2(c) exhibited a good separation of most of the cations notwithstanding the aforementioned issues with some cation peaks overlapping. Out of the four tested methods, the best separation of cations, baseline stability, and sensitivity was achieved with a BGE that consisted of $15 \mathrm{mM}$ imidazole, $8 \mathrm{mM}$ malonic acid, 2 $\mathrm{mM} 18$ crown-6, 10\% v/v methanol, $\mathrm{pH} 4.35$ (using 50\% v/v acetic acid) with separation conditions of $20 \mathrm{kV}, 25^{\circ} \mathrm{C}$, an electromigration injection of $5 \mathrm{kV}$ for 5 s, a bare fused-silica capillary of $75 \mu \mathrm{m}$ i.d. and $56 \mathrm{~cm}$ effective length, and an indirect UV detection of $214 \mathrm{~nm}$ (Figure 2(d)). This method was therefore adopted in this study.

\subsection{Cation Analysis of Standard Mixture}

Reference standards of six selected cations were prepared by the overall dilution of Agilent's cation standard mixture (ammonium, calcium, sodium, potassium, and magnesium) to $25 \mathrm{ppm}$ of each cation and the incorporation of $250 \mathrm{ppm}$ lead from a prepared lead chloride stock solution. Figure 3 shows the electropherogram of the six cations which separated and eluted in less than $12 \mathrm{~min}$ in the following order: ammonium, potassium, calcium, sodium, magnesium, and lead. We note that the lead standard did not elute at lower concentrations suggesting the insensitivity of this method to lead cations. Additionally, the nonsymmetrical peak shape of lead is due to the electrostacking condition [18] [19], which requires that the sample zones and the BGE to have comparable ionic strength. When ions have dissimilar, slower mobilities than the carrier electrolyte, a non-symmetrical peak shape can appear [20]. Peak shape ameliorates as the mobility of the analyte more closely matches that of the compound used for indirect detection [21]. The effects of electrolyte additives, running buffer, $\mathrm{pH}$ 


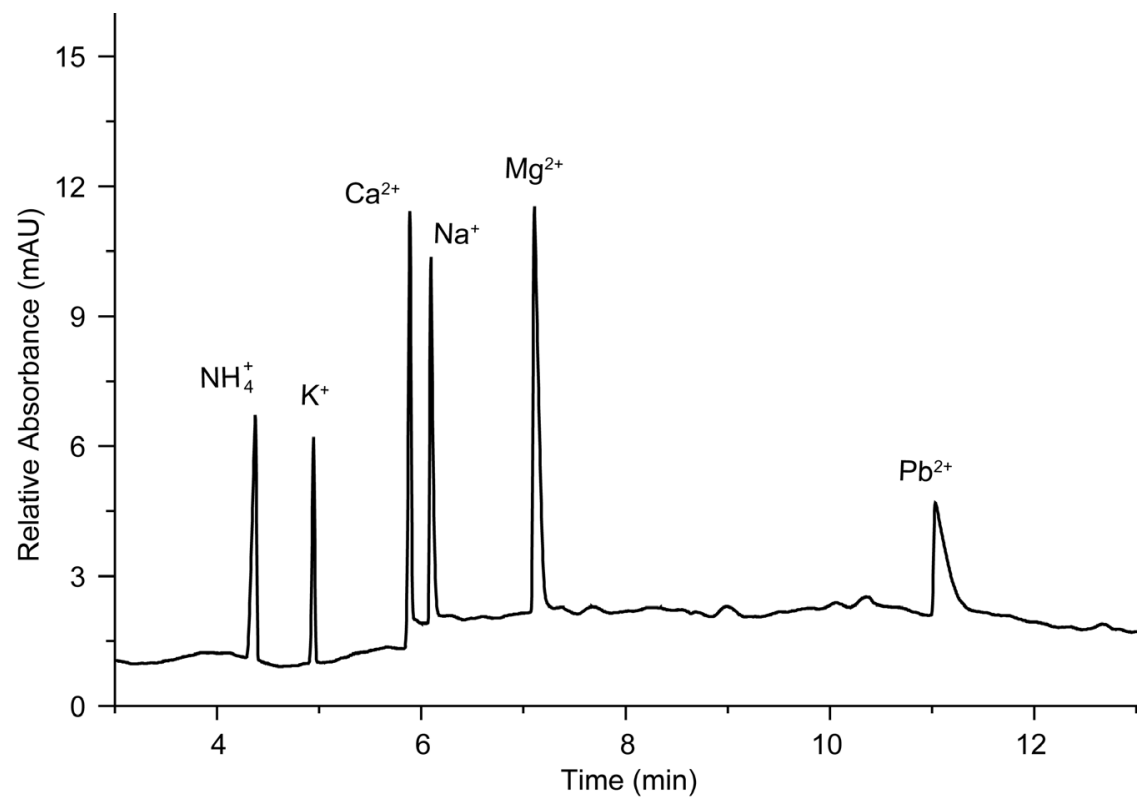

Figure 3. Electropherogram of reference standard cation mixture. The concentration of the ammonium, potassium, calcium, sodium, and magnesium cations was $25 \mathrm{ppm}$ each, and that of lead $250 \mathrm{ppm}$. The BGE is comprised of $15 \mathrm{mM}$ imidazole, $8 \mathrm{mM}$ malonic acid, $2 \mathrm{mM} 18$-crown- 6 ether, $10 \% \mathrm{v} / \mathrm{v} \mathrm{MeOH}$ (pH 4.35 using 50\% v/v acetic acid). Separation conditions: $25^{\circ} \mathrm{C}, 20 \mathrm{kV}$, electromigration injection at $5 \mathrm{kV}$ for $5 \mathrm{~s}$, UV signal detection at $280 \mathrm{~nm}$ with indirect reference of $214 \mathrm{~nm}$.

and other CE conditions on the analysis and separation of cations in drinking water and other solutions have been investigated and optimized in several recent studies [22] [23] [24] [25].

To quantify the amount of detected cations in the water samples, a series of cation standards calibration curves were created (Figure 4). The concentration of the standard cation solutions of ammonium, calcium, magnesium, potassium, and sodium varied between 0.1 and $100 \mathrm{ppm}$. A break in the calibration curve's linearity was consistently observed at around $3 \mathrm{ppm}$ across all tested cations. Therefore, two calibration curves were created for each cation detected in water samples, one at low concentrations $(0.1-3.0 \mathrm{ppm})$ and one for high concentrations $(5.0-100.0 \mathrm{ppm})$. The goodness of the fit is determined from the coefficients of determination, R-squared $\left(\mathrm{R}^{2}\right)$, which averaged 0.88497 for the low concentrations and 0.94819 for the high concentration calibration curves.

\subsection{Analysis of Natural and Wastewater Sources}

Natural water samples were obtained along the Raquette River watershed route, beginning at Bog River Falls, the site nearest upstream to the source (Blue Mountain Lake), continuing downstream towards the St. Lawrence River as far north as Potsdam, NY. The seven sites for which the electropherograms in Figure 5 are displayed (R1 - R7) represent the watershed and wastewater sites analyzed in this study. All tested samples contained calcium, magnesium and sodium. Lead was not detected in any of the samples. The cations detected in all the natural water samples from the Raquette River sites and wastewater sites (R1 - 


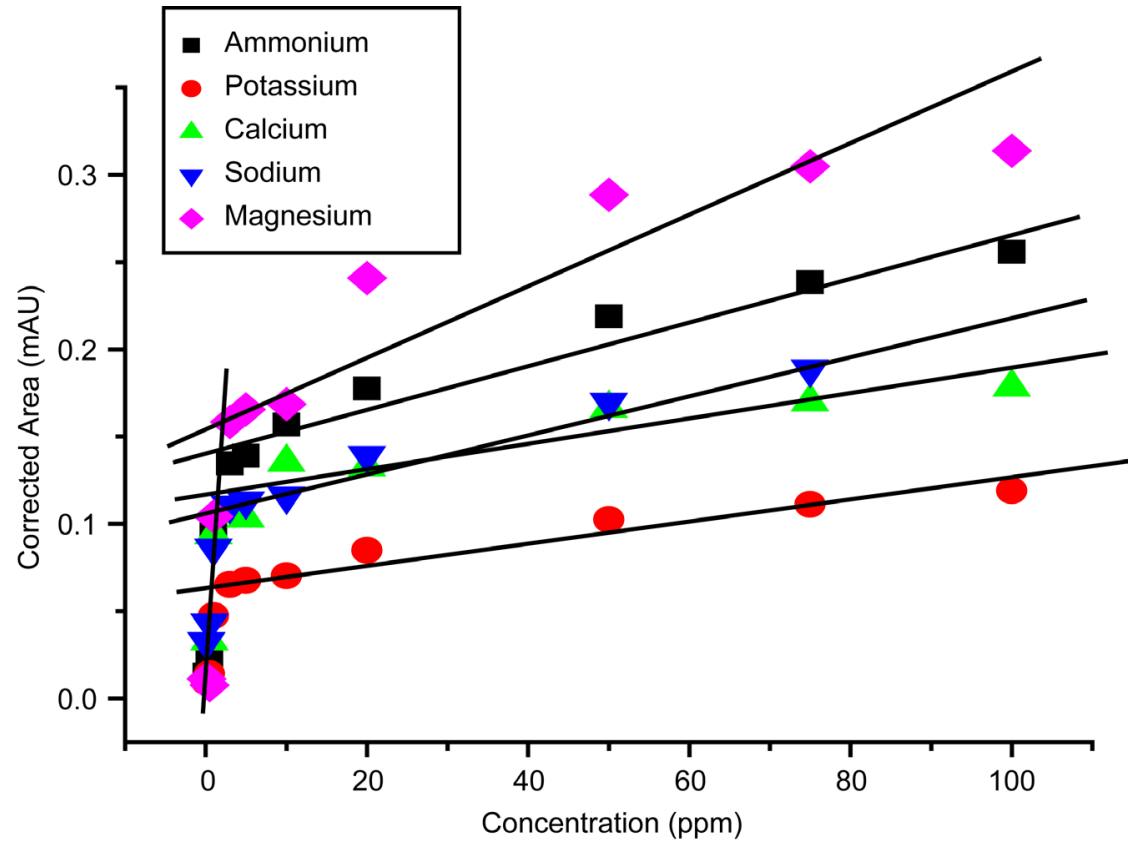

Figure 4. Calibration curves for five cation standards. The low cations concentration (0.1, $0.5,1.0$ and $3.0 \mathrm{ppm}$ ) had an average correlation of 0.88497 . The linear fits for the high cations concentrations $(5,10,20,50,75$, and $100 \mathrm{ppm}$ for ammonium, calcium, magnesium, potassium, and sodium) are shown on the figure.



Figure 5. Electropherograms of water samples taken from (R1) Raquette River at the Crusher, (R2) Pre-WWT in Tupper Lake, (R3) Post-WWT in Tupper Lake, (R4) Carry Falls Reservoir, (R5) South Colton Reservoir, (R6) Pre-WWT in Potsdam, and (R7) Post-WWT in Potsdam. Conditions are as in Figure 3. Peaks: 1, ammonium; 2, potassium; 3, calcium; 4, sodium; 5 , magnesium.

R7, Figure 5) were calcium, magnesium, potassium and sodium. Table 2 displays the sites, sample locations and concentrations in ppm of all the cations tested in this study. The concentration of calcium detected in the samples varied 
between $47 \mathrm{ppm}$ and $364 \mathrm{ppm}$ at the Crusher on Raquette River, upriver from Tupper Lake (R1) and Post-WWT in Tupper Lake (R3), respectively. Magnesium concentrations were found at $0.25 \mathrm{ppm}$ at the Pre-WWT in Tupper Lake (R2) and $1.8 \mathrm{ppm}$ at the Post-WWT in Potsdam (R7). These values are well below NYSDEC's regulated standard concentrations of $35 \mathrm{ppm}$ (Table 1). The levels of potassium ranged from trace amounts of $<0.03 \mathrm{ppm}$ from the Raquette River at the Crusher upriver from Tupper Lake (R1), Carry Falls Reservoir (R4), and South Colton Reservoir (R5) to $0.7 \mathrm{ppm}$ at Pre-WWT in Tupper Lake (R2). Sodium concentration levels were quantified from as low as $2.5 \mathrm{ppm}$ at the PreWWT in Tupper Lake (R2) to as high as $154 \mathrm{ppm}$ at the Post-WWT in Potsdam (R7). All locations (Figure 5, R1, R3 - R7; Table 2), barring the Pre-WWT in Tupper Lake (R2), had sodium levels above NYSDEC standards of $20 \mathrm{ppm}$ (Table 1), keeping in mind NYSDEC does not have regulations for wastewaters in this respect. Ammonium was detected in the samples from the Raquette River at the Crusher (R1), Carry Falls Reservoir (R4), and South Colton Reservoir (R5) in very small concentrations $(<0.5 \mathrm{ppm})$, where the sample from Pre-WWT in Tupper Lake (R2) presented a concentration of $11 \mathrm{ppm}$, which is an expected detection level for wastewater. It is interesting to note that no ammonium was detected in the Pre-WWT sample from Potsdam (R6). This lack of ammonium detection in Potsdam's wastewater could be the result of increased dilution in the sewer system causing the concentration level to drop below detection levels for our method. No ammonium was detected in either of the Post-WWT samples from Tupper Lake (R3) and Potsdam (R7).

\subsection{Potable Water Analysis}

Potable water samples were obtained from taps and wells of various homes and institutions in and around Canton, Potsdam, Tupper Lake, and Brasher FallsWinthrop, NY. All tap and well water samples contained calcium, sodium and magnesium (T1 - T5, Figure 6 and W1 - W3, Figure 7, respectively). Calcium levels ranged from $0.83 \mathrm{ppm}$ at St. Lawrence University (SLU) in Canton (T4) to $186 \mathrm{ppm}$ at State University of New York (SUNY) at Potsdam (T3). Trace amounts of ammonium $(\sim 0.05 \mathrm{ppm})$ were detected in tap samples obtained from the Co-op located in the Village of Tupper Lake (T1), a home located on Mt. Morris in Tupper Lake (T2), and from this author's laboratory at SUNY Potsdam (T3). Trace amounts of potassium $(<0.03 \mathrm{ppm})$ were quantified in the samples taken from the Co-op located in the village of Tupper Lake (T1), a home located on Mt. Morris in Tupper Lake (T2), and a home in the village of Canton (T5).

None of the well water samples contained detectable levels of ammonium, lead or potassium. The well water sample obtained from a home in the town of Potsdam consisted of trace amounts of sodium $(<0.05 \mathrm{ppm})$ and the highest concentration of calcium (755 ppm) than any other site tested. This concentrated level could be due to the fact that the Northern New York geologic region is known to produce hard water for those who have wells as their potable water 


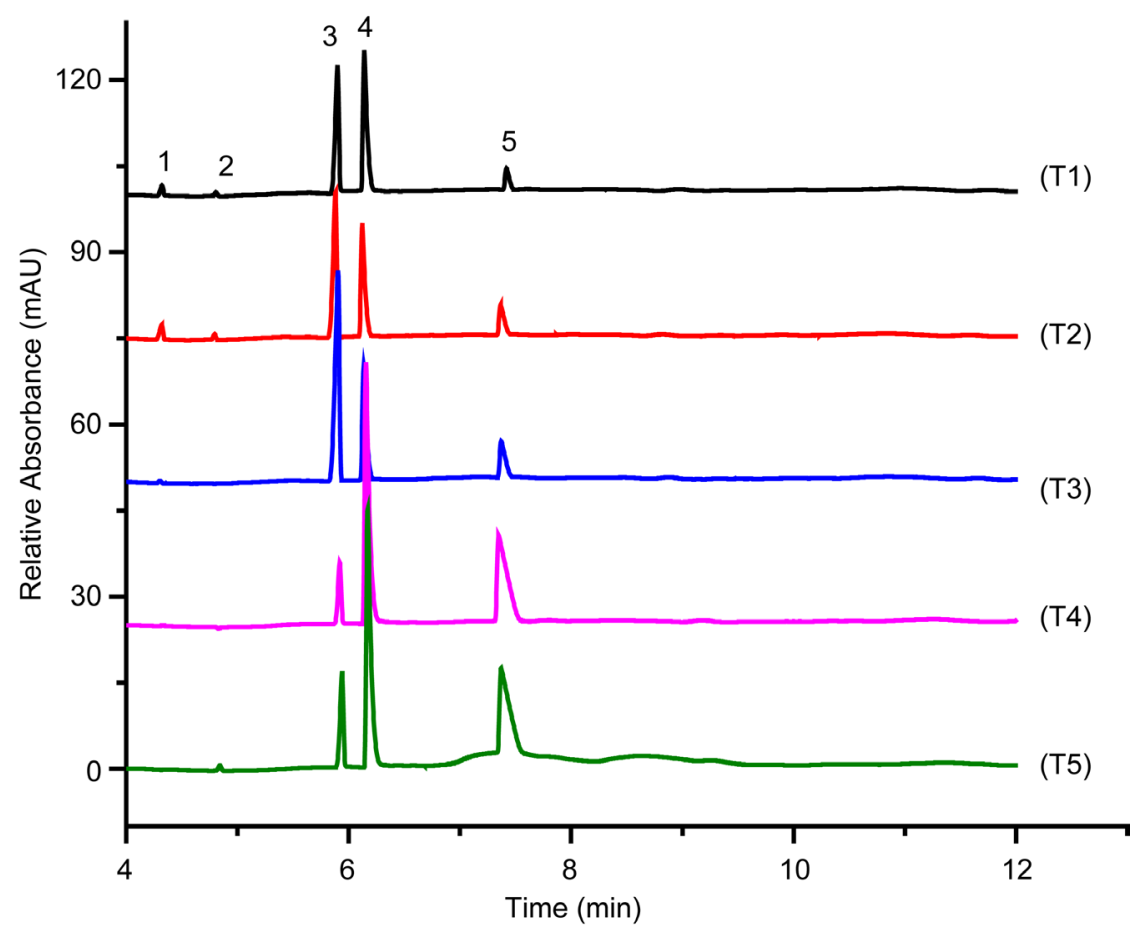

Figure 6. Electropherograms of tap water samples from (T1) Co-op located in village of Tupper Lake, (T2) a home located on Mt. Morris in Tupper Lake, (T3) State University of New York (SUNY) at Potsdam, (T4) St. Lawrence University (SLU) in Canton, and (T5) home in village of Canton. Conditions as in Figure 3. Peaks: 1, ammonium; 2, potassium; 3 , calcium; 4 , sodium; 5 , magnesium.

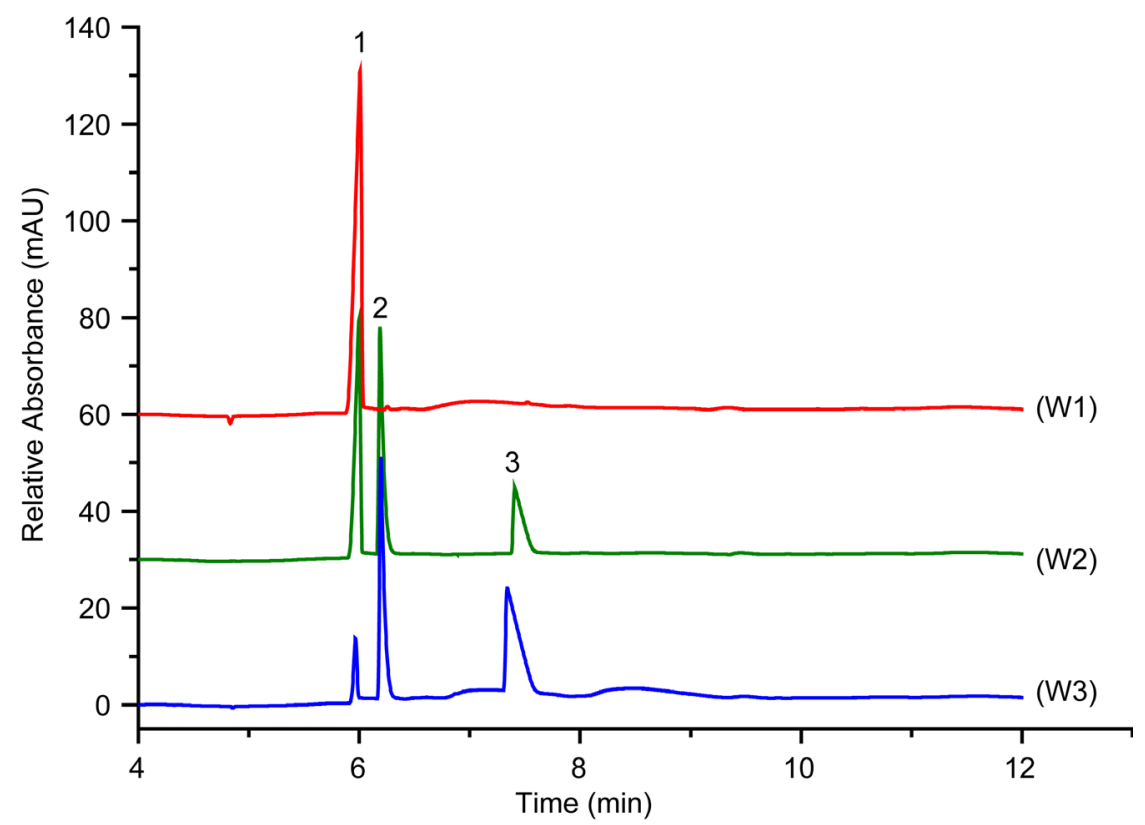

Figure 7. Electropherograms of well water samples from (W1) home in town of Potsdam, (W2) home in town of Canton, and (W3) home in village of Brasher Falls-Winthrop. Conditions as in Figure 3. Peaks: 1, calcium; 2, sodium; 3, magnesium.

source without a properly functional water softener. The other well water samples obtained from the homes in the town of Canton (Figure 7, W2) and village 
of Brasher-Falls/Winthrop (W3) had relatively high concentrations of sodium, and calcium or magnesium. This is not remarkably unusual since calcium and magnesium, in combination with sulfate and carbonate, cause water hardness and is typically found in natural and well waters, which can remain present even with salt additive in water softener systems. At least one of the detected constituents in the well water samples far exceeded the standards dictated by NYSDEC (Table 1), which constitutes only aesthetic properties in terms of the level of water hardness in the case of calcium and magnesium, and in taste for sodium. Although no lead was detected in any of the water samples tested, a more systematic study involving hundreds of samples from older homes is needed to rule out the presence of this heavy metal in the water supply.

\section{Conclusion}

Our study demonstrated that capillary zone electrophoresis (CZE) with indirect UV detection is a sensitive, reliable, and suitable method for the determination of several inorganic cations. The quick, simple and inexpensive sample preparation method makes CZE an appealing tool for the detection and quantification of many cations present in wastewaters, natural waters, and potable waters including tap and well waters. Under our experimental conditions, all tested cations eluted in under $12 \mathrm{~min}$ with excellent linearity and reproducibility. No lead was detected in any of the tested water samples, including wastewaters, although a more systematic study is required to rule out the presence of this toxic heavy metal in the water supply. Ammonium levels detected were well under the standard limits as dictated by NYSDEC. Although the concentrations of magnesium and sodium in several of the samples tested were above NYSDEC standards, the violation was mostly in regards to aesthetics and not adverse health effects, with the exception of excessively high sodium levels which may contribute to an increase in blood pressure.

\section{Acknowledgements}

This work was supported by the National Institute of Health Award Number R15GM104879, the T. Urling and Mabel Walker Research Fellowship Program, and the Collegiate Science and Technology Entry Program (CSTEP) at SUNY Potsdam. The authors would like to acknowledge Scott Varden for his valuable inputs on this project and assistance with sample collections.

\section{References}

[1] Tiselius, A.A. (1937) New Apparatus for Electrophoretic Analysis of Colloidal Mixtures. Transactions of the Faraday Society, 33, 524-531. https://doi.org/10.1039/tf9373300524

[2] Jorgenson, J.W. and Lukas, K.D. (1981) Zone Electrophoresis in Open-Tubular Glass Capillaries. Analytical Chemistry, 53, 1298-1302. https://doi.org/10.1021/ac00231a037

[3] Knox, J. (1988) Thermal Effects and Band Spreading in Capillary Electro-Separation. Chromatographia, 26, 329-337. https://doi.org/10.1007/BF02268176 
[4] Rahmi, D., Zhu, Y.B., Fujimori, E., Umemura, T. and Haraguchi, H. (2007) Multielement Determination of Trace Metals in Seawater by ICP-MS with Aid of Down-Sized Chelating Resin-Packed Minicolumn for Preconcentration. Talanta, 72, 600-606. https://doi.org/10.1016/j.talanta.2006.11.023

[5] Fung, Y.S. and Lau, K.M. (2006) Separation and Determination of Cations in Beverage Products by Capillary Zone Electrophoresis. Journal of Chromatography A, 118, 144-150. https://doi.org/10.1016/j.chroma.2006.04.030

[6] Tangen, A., Lund, W. and Frederiksen, R.B. (1997) Determination of $\mathrm{Na}^{+}, \mathrm{K}^{+}, \mathrm{Mg}^{2+}$ and $\mathrm{Ca}^{2+}$ in Mixtures of Seawater and Formation Water by Capillary Electrophoresis. Journal of Chromatography A, 767, 311-317. https://doi.org/10.1016/S0021-9673(97)00007-1

[7] Kuban, P. and Karlberg, B. (1998) Simultaneous Determination of Small Cations and Anions by Capillary Electrophoresis. Analytical Chemistry, 70, 360-365. https://doi.org/10.1021/ac9706133

[8] Padarauskas, A., Olšauskaite, V. and Schwedt, G. (1998) Simultaneous Separation of Inorganic Anions and Cations by Capillary Zone Electrophoresis. Journal of Chromatography A, 800, 369-375. https://doi.org/10.1016/S0021-9673(97)01108-4

[9] Padarauskas, A., Olšauskaite, V. and Paliulionyte, V. (1998) Simultaneous Determination of Inorganic Anions and Cations in Waters by Capillary Zone Electrophoresis. Journal of Chromatography A, 829, 359-365. https://doi.org/10.1016/S0021-9673(98)00883-8

[10] Haumann, I., Boden, J., Mainka, A. and Jegle, U. (2000) Simultaneous Determination of Inorganic Anions and Cations by Capillary Electrophoresis with Indirect UV Detection. Journal of Chromatography A, 895, 269-277. https://doi.org/10.1016/S0021-9673(00)00667-1

[11] Liu, W. and Lee, H.K. (1999) Simultaneous Analysis of Lead, Mercury and Selenium Species by Capillary Electrophoresis with Combined Ethylenediaminetetraacetic Acid Complexation and Field-Amplified Stacking Injection. Electrophoresis, 20, 2475-2483.

https://doi.org/10.1002/(SICI)1522-2683(19990801)20:12<2475::AID-ELPS2475>3.0 .CO;2-M

[12] Gao, J., Sun, X., Yang, W., Fan, H., Li, C. and Mao, X. (2008) Separation and Determination of Six Metal Cations by Capillary Zone Electrophoresis. Journal of the Chilean Chemical Society, 53, 1431-1434. https://doi.org/10.4067/S0717-97072008000100020

[13] Hiissa, T., Sirén, H., Kotiaho, T., Snellman, M. and Hautojärvi, A. (1999) Quantification of Anions and Cations in Environmental Water Samples: Measurements with Capillary Electrophoresis and Indirect-UV Detection. Journal of Chromatography $A$, 853, 403-411. https://doi.org/10.1016/S0021-9673(99)00508-7

[14] Major Ions in Water (2002) Hydrology Project Training Module File, Version 05.

[15] US Environmental Protection Agency (1972) Summary of the Clean Water Act: 33 USC $\$ 1251$ et seq. https://www.epa.gov

[16] New York State Department of Environmental Conservation. 6 CRR-NY 703.5 Water Quality Standards for Taste-, Color- and Odor-Producing, Toxic and Other Deleterious Substances. http://www.dec.ny.gov

[17] Padarauskas, A., Olšauskaitè, V. and Paliulionyte, V. (1998) New Electrolyte System for the Determination of Ammonium, Alkali and Alkaline Earth Cations by Capillary Electrophoresis. Analytica Chimica Acta, 374, 159-165. https://doi.org/10.1016/S0003-2670(98)00287-6

[18] Jandik, P., Bonn, G. and Jandik, P. (1993) Capillary Electrophoresis of Small Mole- 
cules and Ions. VCH Publishers Inc., New York, 80-82.

[19] Hjertén, S. (1990) Zone Broadening in Electrophoresis with Special Reference to High-Performance Electrophoresis in Capillaries: An Interplay between Theory and Practice. Electrophoresis, 11, 665-690. https://doi.org/10.1002/elps.1150110904

[20] Oehrle, S.A. (1996) Analysis of Anions in Drinking Water by Capillary Ion Electrophoresis. Journal of Chromatography $A, 733,101-104$. https://doi.org/10.1016/0021-9673(95)00769-5

[21] Pursell, C.J., Chandler, B. and Bushey, M.M. (2004) Capillary Electrophoresis Analysis of Cations in Water Samples: An Experiment for the Introductory Laboratory. Journal of Chemical Education, 81, 1783-1786. https://doi.org/10.1021/ed081p1783

[22] Shi, M., Gao, Q., Feng, J. and Lu, Y. (2012) Analysis of Inorganic Cations in Honey by Capillary Zone Electrophoresis with Indirect UV Detection. Journal of Chromatographic Science, 50, 547-552. https://doi.org/10.1093/chromsci/bms032

[23] Chen, W., Gao, F., Zhang, Y., Zhang, Y., Li, Y., Zhang, Y., Wang, Q. and He, P. (2016) Sensitive Determination of Metal Ions in Drinking Water by Capillary Electrophoresis Coupled with Contactless Conductivity Detection Using 18-Crown-6 Ether and Hexadecyltrimethylammonium Bromide as Complexing Reagents. American Journal of Analytical Chemistry, 7, 737-747. https://doi.org/10.4236/ajac.2016.711066

[24] Koenka, I.J., Mai, T.D., Hauser, P.C. and Saiz, J. (2016) Simultaneous Separation of Cations and Anions in Capillary Electrophoresis-Recent Applications. Analytical Methods, 8, 1452-1456. https://doi.org/10.1039/C5AY02917A

[25] Elbashir, A.A. and Aboul-Enein, H.Y. (2010) Application of Crown Ethers as Buffer Additives in Capillary Electrophoresis. Current Pharmaceutical Analysis, 6, 101 113. https://doi.org/10.2174/157341210791202618

\section{Scientific Research Publishing}

Submit or recommend next manuscript to SCIRP and we will provide best service for you:

Accepting pre-submission inquiries through Email, Facebook, LinkedIn, Twitter, etc. A wide selection of journals (inclusive of 9 subjects, more than 200 journals)

Providing 24-hour high-quality service

User-friendly online submission system

Fair and swift peer-review system

Efficient typesetting and proofreading procedure

Display of the result of downloads and visits, as well as the number of cited articles

Maximum dissemination of your research work

Submit your manuscript at: http://papersubmission.scirp.org/

Or contactajac@scirp.org 